\title{
Forest Recovery in Newly Abandoned Pastures in Southern Brazil: Implications for the Atlantic Rain Forest Resilience
}

\author{
Kwok Chiu Cheung, Dieter Liebsch \& Marcia Cristina Mendes Marques*
}

\author{
Laboratório de Ecologia Vegetal, Departamento de Botânica, Setor de Ciências Biológicas, \\ Universidade Federal do Paraná - UFPR, CP 19031, CEP 81531-980, Curitiba, PR, Brasil
}

\begin{abstract}
Replacing the Brazilian Atlantic Forest by pastures has caused a strong impact on this biome. Hence, to evaluate the forest recovery after removing disturbance is a key factor to conserve biodiversity. In this study we analyzed changes in forest structure in five abandoned pastures in southern Brazil, aiming to verify the direction and rate of structural and functional changes in the early succession. The abandoned pastures (by periods of 8, 14, 48, 50 and 96 months) were colonized mainly by trees, animal-dispersed and pioneer species. The data showed that the forest structure was quickly changed with an increase in tree abundance, stem volume and species richness. It indicates that in low fragmented landscapes, such as the northern littoral of Parana State, the resilience of the Atlantic Forest is relatively high and assisted regeneration may be an option to biodiversity conservation strategies.
\end{abstract}

Key words: Ecological Succession, Natural Regeneration, Tropical Forest.

\section{Introduction}

The conversion of forests to pastures has been a typical activity in tropical landscapes in the last decades (Aide et al. 2000, Holl et al. 2000). Despite the fact that cattle raising can improve goods and gains for landowners during few years, the soil exhaustion, the decreasing in productivity and changes in regional economy frequently obligate the farmers to abandon this activity (Florentine and Westbrooke 2004). Thus, abandoned pastures constitute a common situation in tropical lands where ecosystem structure and function are drastically changed and forest recovery is necessary to rescue the regional diversity (Cusack \& Montagnini 2004).

The vegetation removal and the introduction of pastures give rise to a set of changes, including the soil chemical and physical exhaustion and the persistence of exotic grasses (Guggenberg \& Zech 1999, Guariguata and Ostertag 2001). In addition, the pasture management usually demands activities such as burning, soil plowing and tree sprouting limitation that strongly affect the

\footnotetext{
${ }^{\star}$ Send correspondence to: Marcia Cristina Mendes Marques Laboratório de Ecologia Vegetal, Departamento de Botânica, Setor de Ciências Biológicas,

Universidade Federal do Paraná - UFPR,

CP 19031, CEP 81531-980, Curitiba, PR, Brasil

E-mail:mmarques@ufpr.br
}

habitat for plant establishment (Guggenberg \& Zech 1999). Recovering previous environmental conditions and limiting grasses growth are two of the most difficult steps to restore abandoned pastures.

The intensity of soil use for pasture may determine the time for the forest regeneration (Liebsch et al. 2008). For instance, in strongly disturbed soils by pasture, the seed bank is affected (Gomez-Pompa \& Vázquez-Yanes 1981), seedling establishment and growth is altered (Uhl et al. 1988) and the succession process leads to an undesired forest structure (Pascarella et al. 2004). Loosing resilience limits the ecosystem recovery, then demanding the use of restoration practices to rescue the structure and function of tropical landscapes (Aide et al. 1995, Holl 1999, Holl et al. 2000, Miyawaki 2004).

Changes in forest structure, species composition, and plant functional groups follow a more or less defined pattern in tropical forests during the secondary succession (Guariguata \& Ostertag 2001, Chazdon 2002). In general, the forest recovery is characterized by the increase in species richness, stem abundance and biomass, and a progressive increase in woody, zoochoric and non-pioneer species (Guariguata \& Ostertag 2001). The rate of plant community changes, nevertheless, may differ strongly among forests (Chazdon 2008) and the succession process in disturbed areas may be 
less efficient to recover diversity. Thus, evaluating changes in forest structure in abandoned pastures is an important step to verify the resilience of these systems, helping to develop appropriate protocols for conservation of tropical forests.

The Atlantic Rain Forest, once found along the whole Brazilian littoral, was strongly reduced, being replaced by urban regions and farms (Ribeiro et al. 2009). In the southern Brazil, for example, large areas of forest were converted into pastures for buffaloes grazing and afterwards abandoned. In this study we aimed to quantify the resilience of the Atlantic Rain Forest by assessing the vegetation structure after 8, 14, 48, 50 and 96 months of pasture abandonment in this region. We verified if forest structure (i.e. species richness, individual abundance and stem volume) and species attributes (i.e. life forms, dispersal modes and successional groups) change proportionally with time since abandonment, therefore quantifying the resilience.

\section{Material and Methods}

The study was carried out at the Rio Cachoeira Reserve, situated in the municipality of Antonina (Parana State), southern coast of Brazil. The region (Guaraqueçaba protected area) is one of the most important fragments of Atlantic Forest in Brazilian littoral and it is characterized by large areas of secondary forests ( $~ 50 \%$ of the area), mature forests $(\sim 5 \%)$ and cattle raising farms $(\sim 45 \%)$ (Ferretti \& Britez 2006). We choose five plots where the buffaloes were removed and the pasture was abandoned by $8,14,48,50$ and 96 months before the experiment. In each plot we sampled trees and shrubs $\geq 1 \mathrm{~m}$ in height in $600 \mathrm{~m}^{2}$ (24 quadrats of $5 \times 5 \mathrm{~m}$ ). Details of sample design, species checklist and analysis are found in the Supplementary Material and in Cheung et al. (2009). We calculated the species richness, total density, volume and functional group percentage for each plot. We performed linear regressions to determine the relationships between the time after the abandon and the ecological groups and vegetation structure. In each model, we used the angular coefficient (b) to compare the rate of structural changes in species differing in life forms, dispersal modes and successional group.

\section{Results}

In the five plots were sampled in total 2.234 individuals of 104 species. The abandoned areas were colonized mainly by trees (91\% species), animal-dispersed (67\%) and pioneer species $(62 \%)$. The abundance, stem volume and species richness presented large variation among quadrants within a plot (variation coefficient from 35 to $460 \%$; Table S1, see http://www.abecol.org.br/natureza.html). It suggests that variations at small scales (for example in soil characteristics or distance from the seed source) are sufficient to cause differences in the forest regeneration. Despite it, the direction and rate of forest structure recovery were clearly determined during the succession. The percentage of trees, animal-dispersed species and non-pioneer species increased during the forest recovery (Figure 1), but the increasing rate of non-pioneer species (given by $\mathrm{b}=0.45$ ) is almost the double of the rate for the tree species $(b=0.28)$ and the animal-dispersed species $(b=0.22)$.

Contrasting with the decreasing of shrubs, tree abundance, species richness and stem volume increased with time after the pasture abandonment (Figure 2). The rate of structural changes differed among life forms: changes in abundance, species richness and volume were higher in trees (respectively, $\mathrm{b}=5.31,0.53$ and 0.16 ) than in shrubs (respectively, $\mathrm{b}=-3.21,-0.03$ and -0.01 ).

\section{Discussion}

The forest recovery in newly abandoned pastures in southern Brazil was a relatively fast and efficient process, resulting in structurally defined young forests. The colonization by pioneer and animal-dispersed species quickly changed the
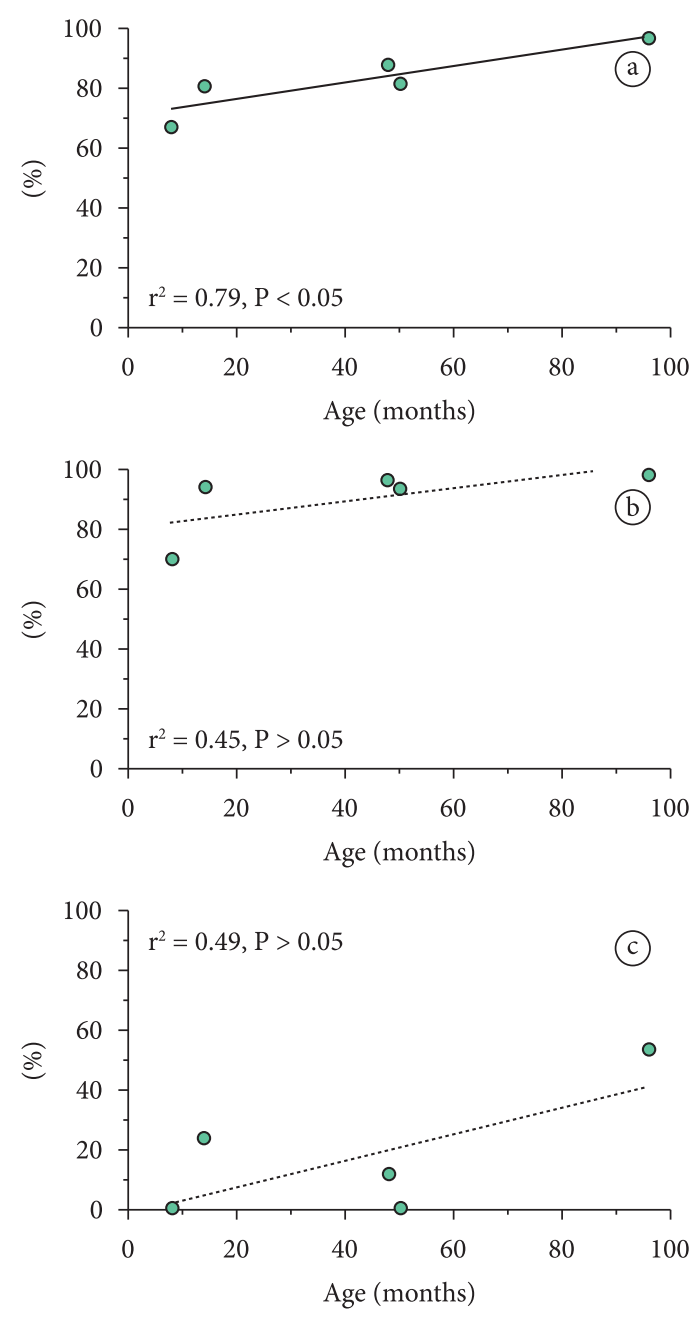

Figure 1. Changes in the percentage of ecological groups in the forest recovery in newly abandoned pastures in Southern Brazil. a) tree species; b) animal-dispersed species; c) non-pioneer species. 

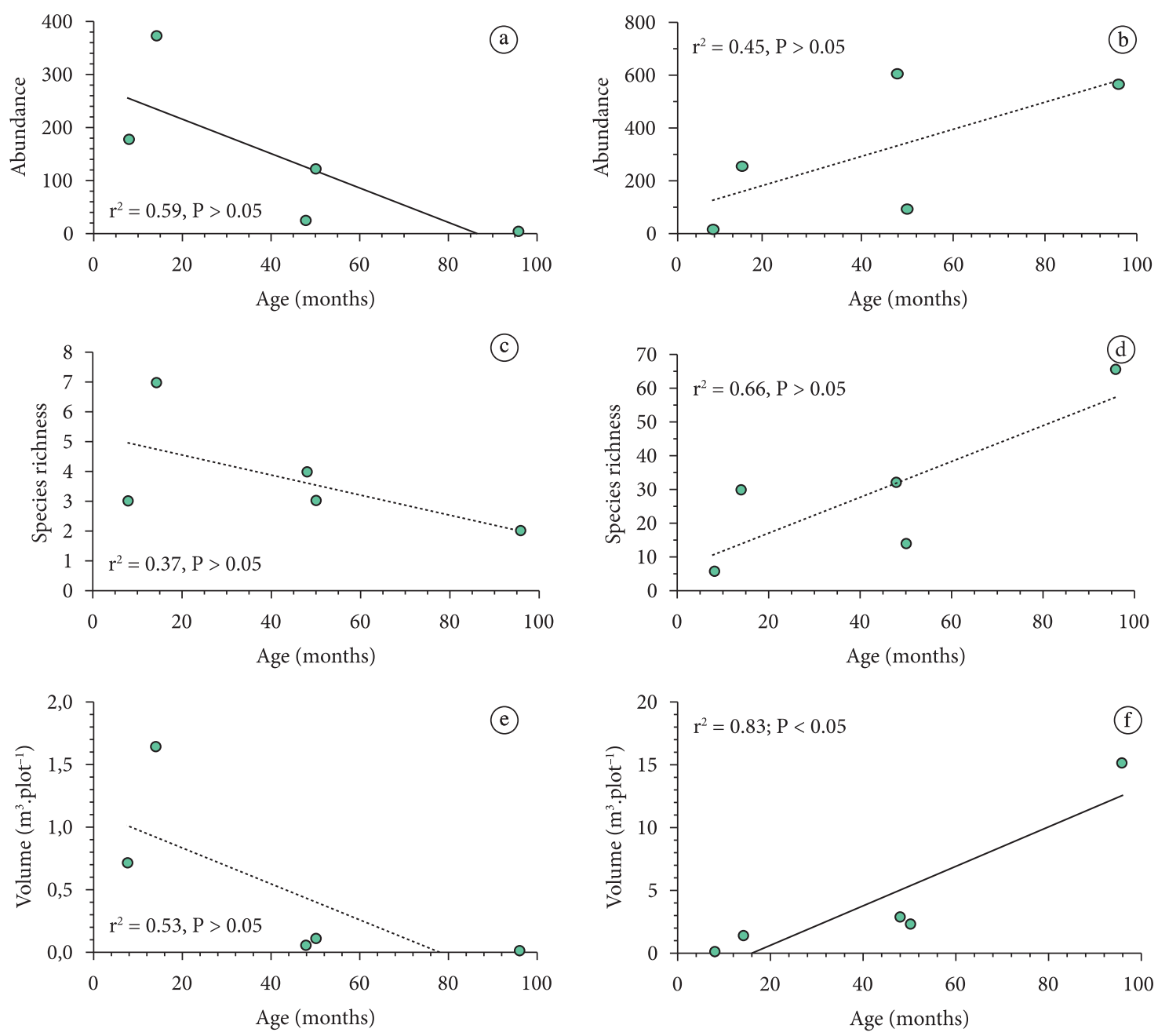

Figure 2. Changes in structure (abundance, species richness and stem volume) of in the forest recovery in newly abandoned pastures in Southern Brazil. a, c, d) shrubs; b, d, f) trees.

vegetation structure resulting in young forests dominated by trees and non-pioneer species from the neighbor forests, after few years of pasture abandonment. These findings point to the potential resilience of the Atlantic Forests in low fragmented landscapes.

The four years succession in the abandoned forests resulted in 94 tree species (total of five areas), about $28 \%$ of tree species that occur in secondary and mature forests in Rio Cachoeira reserve (M. Borgo, pers. com.). During the last decades the region was highly modified since the original forests were first replaced by pastures and then turned into secondary forests (this latter being an important font of seeds). In fact, seed limitation (Muller-Landau et al. 2002) is one of the most important factors affecting forest regeneration and succession (Holl 1999, Holl et al. 2000). Nevertheless, due to the small distance among secondary forest fragments, animal movement is not totally limited allowing seed arrival in abandoned pastures. Even in the youngest abandoned pasture ( 8 months), the percentage of animal-dispersed species was higher than $75 \%$, indicating the importance of large fragments - e.g., to serve as animal refuge - to forest recovery. Pioneer and animal dispersed species such as Miconia cinerascens var. robusta, Myrsine coriacea and Hyeronima alchorneoides are especially important in these areas (Cheung et al. 2009) because of their potential for attracting birds and increasing seedling establishment (R. Pamplona, pers. com.). Thus, the animal dispersal is an important factor accelerating the forest recovery in this region compared with highly fragmented Atlantic Rain Forest in Brazil (Tabarelli \& Peres 2002).

The succession in abandoned pastures was characterized by the increase in tree, animal-dispersed and non-pioneer species. Changes in functional groups are expected during forest regeneration (Liebsch et al. 2008), but losses in key functional groups strongly mischaracterize forests in highly fragmented landscapes (Tabarelli et al. 1999). We found that the rate of increasing of non-pioneer species is the double of that for trees and animal dispersed species. Such 
differences indicate that the newly abandoned pastures are initially colonized by tree and animal dispersed species that support the arrival of non-pioneer species. Thus, the facilitation of these species is an important aspect for the forest succession.

Structural changes in the young forests include the increase in tree abundance, species richness and volume and decrease of shrub-related vegetation parameters. This substitution of woody species during the succession is expected in tropical forests (Gómez-Pompa \& Vázquez-Yanes 1981, Guariguata \& Ostertag 2001). Shrub species are able to quickly colonize the newly abandoned pastures just after the cattle are removed from the area. These shrubs comprise short lived species, dispersed by animal or wind, promoting the first changes in shading and soil characteristics of the disturbed area (pers. obs.).

The recovery of forest structure during the succession in tropical forests is a variable process (Chazdon 2008). Whereas the volume (biomass or basal area) increases approximately directly with the time (Veblen 1992), stem abundance and species richness recovery may describe less predictable trajectories. Some studies in chronosequences showed an increase in stem abundance and species richness in the first decades of forest succession and decrease in old growth forests (Aide et al. 2000, Chinea 2002). In the Rio Cachoeira reserve the first years of succession showed an increasing abundance, species richness and stem volume. However, it is possible that the mortality of short-lived species alters forest structure in the next steps of the succession. In fact, Liebsch et al. (2007) found a lower abundance and species richness in old growth forests in the region.

The linear models on forests structural changes according to the time after abandonment showed a clear increase in tree abundance, species richness and stem volume. These results suggest that, at small scale (here only four years) the succession in abandoned pastures is dynamic and relatively fast in the region. However, despite strong evidences of the successional direction, there were differences among areas and no unique pattern was found in Rio Cachoeira reserve. The variation in abundance, species richness and stem volume among areas (Figure 1) and within areas $(34 \%<\mathrm{CV}<460 \%)$ suggests that several successional processes occur in the region, at the same time. Besides seed limitation, the conditions for seedling establishment vary among sites, because of the time of land use and soil degradation. The establishment limitation strongly affects the vegetation recover in tropical degraded areas (Aide et al. 1995, Guggenberg \& Zech 1999). Thus, whereas seed arrival is a minor factor affecting forest recovery in Rio Cachoeira reserve, establishment limitation probably caused differences among areas. For example, the 50-months area was impoverished in species richness and tree abundance compared to the younger ones. Probably, problems in soil drainage (caused by the soils compaction) associated to the fast grass growth limited the seedling establishment (Cheung et al. 2009). Soil compaction and nutrient exhaustion is a known factor reducing regeneration in abandoned pastures (Uhl et al. 1988, Aide et al. 1995, Pinard et al. 2000, Zimmerman et al. 2000). Thus, despite fast forest recovery, specific environmental conditions may limit the succession and should be considered in restoration programs.

The capacity of forest recovery after removing the disturbance is the key factor to conserve the Atlantic Rain Forest in Brazil. The fast forest recovery, by assisted regeneration, in the relatively low fragmented northern littoral of Parana State suggests that resilience can be improved in areas next to secondary and mature forests.

\section{Acknowledgements}

This study was financially supported by Brazilian Research Council (CNPq) (Solobioma Project, 690148/01-1), the German Federal Ministry of Education and Research (BMBF project number 01LB0201), and the Fundação O Boticário de Proteção à Natureza. We thank the support of the SPVS for allowing us to work at Cachoeira Nature Reserve and their staff for field work assistance. We also thank José M. Torezan and Marcos G. E. Luz for comments and suggestions to the manuscript. M.C.M. Marques received a productivity grant from CNPq (Processo 308597/2008-7).

\section{References}

Aide TM et al., 1995. Forest recovery in abandoned tropical pastures in Puerto Rico. Forest Ecology and Management, 77:77-85.

Aide TM et al., 2000. Forest regeneration in a chronosequence of tropical abandoned pastures: implications for restoration ecology. Restoration Ecology, 8:328-338.

Chazdon RL, 2008. Chance and determinism in tropical forest succession. In: Carson WP and Schnitzer SA (eds.). Tropical Forest Community Ecology. Oxford: Wiley-Blackwell. p. 384-408.

Cheung KC, Marques MCM \& Liebsch D, 2009. Relação entre a presença de vegetação herbácea e a regeneração natural de espécies lenhosas em pastagens abandonadas na Floresta Ombrófila Densa do Sul do Brasil. Acta botanica Brasilica, 23:1048-1056.

Chinea JD, 2002. Tropical forest succession on abandoned farms in the Humacao Municipality of eastern Puerto Rico. Forest Ecology and Management, 167:195-207.

Cusack D \& Montagnini F, 2004. The role of native species plantations in recovery of understorey woody species in degraded pasturelands of Costa Rica. Forest Ecology and Management, 188:1-15.

Ferretti AR \& Britez RM, 2006. Ecological restoration, carbon sequestration and biodiversity conservation: The experience of the Society for Wildlife Research and Environmental Education (SPVS) in the Atlantic Rain Forest of Southern Brazil. Journal for Nature Conservation, 14: 249-259.

Florentine SK \& Westbrooke ME, 2004. Restoration on abandoned tropical pasturelands - do we know enough? Journal of Nature Conservation, 12:85-94 
Gomez-Pompa A \& Vázquez-Yanes C, 1981. Sucessional studies of a rain forest in Mexico. In West DC, Shugar HH and Botkin DB (eds.). Forest Sucession: concepts and aplications. New York: Spriger-Verlag. p. 246-266.

Guariguata MR \& Ostertag R, 2001. Neotropical secondary forest succession: changes in structural and funcional characteristics. Forest Ecology and Management, 148:185-206.

Guggenberg G \& Zech W, 1999. Soil organic matter composition under primary forest, pasture and secondary forest sucession, Región Huetar Norte, Costa Rica. Forest Ecology and Management, 124:96-104.

Holl KD, 1999. Factors limiting tropical rain forest regeneration in abandoned pasture: seed rain, seed germination, microclimate and soil. Biotropica, 31:229-242.

Holl KD et al., 2000. Tropical montane forest restoration in Costa Rica: overcoming barriers to dispersal and establishment. Restoration Ecology, 8:339-349.

Holl KD, 2002. Effect of shrubs on tree seedling establishment in an abandoned tropical pasture. Journal of Ecology, 90:179-187.

Liebsch D, Goldenberg R \& Marques MCM, 2007. Florística e estrutura de comunidades vegetais em uma cronoseqüência de Floresta Atlântica no Paraná. Acta botanica Brasilica, 21:983-992.

Liebsch D, Marques MCM \& Goldenberg R, 2008. How long does the Atlantic Rain Forest take to recover after a disturbance? Changes in species composition and ecological features during secondary succession. Biological Conservation, 141:1717-1725.

Miyawaki A, 2004. Restoration of the living environment based on vegetation ecology: theory and practice. Ecological Research, 19:83-90.
Muller-Landau HC, et al., 2002. Assessing recruitment limitation: concepts, methods and case-studies from a tropical forest. In Levey DJ, Silva WR and Galetti M (eds.). Seed dispersal and frugivory: ecology, evolution and conservation. Wallingford. p. 35-53.

Pascarella JB, Aide TM \& Zimmerman JK, 2004. Short-term response of secondary forest to hurricane disturbance in Puerto Rico, USA. Forest Ecology and Management, 199:379-393.

Pinard MA, Baker MG \& Tay J, 2000. Soil disturbance and post-logging forest recovery on bulldozer paths in Sabah, Malaysia. Forest Ecology and Management, 130:213-225.

Ribeiro NC et al., 2009. The Brazilian Atlantic Forest: How much is left, and how is the remaining forest distributed? Implications for conservation. Biological Conservation, 142:1141-1153.

Tabarelli M, Mantovani W \& Peres CA, 1999. Effects of habitat fragmentation on plant guild structure in the montane Atlantic forest of southeastern Brazil. Biological Conservation, 91:119-127.

Tabarelli M \& Peres CA, 2002. Abiotic and vertebrate seed dispersal in the Brazilian Atlantic Forest: implications for forest regeneration. Biological Conservation, 106:165-176.

Uhl C, Buschbacker R \& Serrão EAS, 1988. Abandoned pastures in eastern Amazonia I. Patterns of plant succession. Journal of Ecology, 76:663-681.

Veblen TT, 1992. Regeneration dynamics. In Glenn-Lewin DC, Peet RK and Veblen TT (eds.). Plant succession: theory and prediction. London: Chapman \& Hall. p. 152-187.

Zimmerman JK, Pascarella JB \& Aide TM, 2000. Barriers to forest regeneration in an abandoned pasture in Puerto Rico. Restoration Ecology, 8:350-360.

Received: June 2010

First Decision: June 2010

Accepted: June 2010 